\title{
Alfalfa crops amended with MSW compost can compensate the effect of salty water irrigation depending on the soil texture
}

\author{
Sonia Mbarki ${ }^{a, b, *}$, Artemi Cerdà ${ }^{c}$, Marek Ziucak ${ }^{d}$, Marian Brestic ${ }^{d}$, \\ Mokded Rabhi ${ }^{a}$, Mejid Mezni ${ }^{e}$, Naceur Jedidi ${ }^{f}$, Chedly Abdelly ${ }^{a}$, \\ Jose Antonio Pascual ${ }^{b}$ \\ ${ }^{a}$ Laboratory of Plant Extremophiles, Biotechnology Center at the Technopark of Borj-Cedria, Tunisia \\ $\mathrm{b}$ Department of Soil Water Conservation and Organic Waste Management, Centro de Edafología y Biología Aplicada \\ del Segura, Murcia, Spain \\ c Soil Erosion and Degradation Research Group, Department of Geography, Universitat de València, Spain \\ d Department of Plant Physiology, Slovak University of Agriculture, Nitra, Slovak Republic \\ e Laboratory of Animal and Forage Productions, INRAT, Tunisia \\ ${ }^{\mathrm{f}}$ Laboratory of Treatments Wastes Water, Center of Water Research and Water Technologies at the Technopol of \\ Borj-Cedria, Tunisia
}

\section{A R T I C L E I N F O}

\section{Article history:}

Received 10 April 2017

Received in revised form 30 July 2017

Accepted 3 September 2017

Available online xxx

\section{Keywords:}

Salinity

Remediation

Restoration

Desertification

Arid

Irrigation

Crop

Alfalfa

\begin{abstract}
A B S T R A C T
The availability of water resources of marginal quality such as drainage water or high-salt containing groundwater is turning into an important issue in Tunisia and other countries with scarce water resources. A pot experiment was carried out to evaluate plant production, nutrient content and heavy metal bioaccumulation in agricultural soils amended with MSW compost and irrigated with salty water, by using two different soil textures (clay and sandy). Salt water supply decreased plant dry yield in both soils. Salt stress had significantly reduction in plant biomass in sandy soil compared to those in clay soil (biomass of dry weight is significantly higher in clay soil than those in sandy soil in presence of salt: percentage of growth compared to control was 55\% for clay soil and $45 \%$ for sandy soil). The application of Municipal Solid Wastes (MSW) Compost increased significantly alfalfa productivity in both soils (Dry weight is significantly higher in presence of compost: $140 \%$ for clay soil and $125 \%$ for sandy soil). In non-amended soil, the growth was reduced significantly by salt stress ( $50 \%$ in clay soil, $26 \%$ in sandy compared to the soils without salty water application). Plants irrigated with salty water accumulated much more sodium on sandy soil $\left(1.74 \mathrm{mmol} \mathrm{g}^{-1}\right)$ than on clay one $\left(0.87 \mathrm{mmol} \mathrm{g}^{-1} \mathrm{DW}\right)$. Compost did not reduce sodium accumulation in aerial parts on sandy soil, whereas it slightly reduced it in those grown on clay soil. Zinc $(\mathrm{Zn})$, Copper $(\mathrm{Cu})$, Lead $(\mathrm{Pb})$ and Cadmium (Cd) concentrations showed the same trend for both soil types. They increased statistically significant by salinity to 124-189\%, the highest rise was found in Cu concentration on clay soil. The order of metal uptake was: $\mathrm{Zn}>\mathrm{Cu}>\mathrm{Pb}>\mathrm{Cd}$. A higher significant shoot accumulation of heavy metals (up to $305 \%$ of the control) was noticed in the presence of compost with no difference between salt-treated and non-treated. MSW compost amendment caused an increase of the studied heavy metals in alfalfa shoots grown that was higher on sandy soils than clay soils. Heavy metals in plants remained lower than phytotoxic level and these level of accumulation did
\end{abstract}

\footnotetext{
* Corresponding author at: Soil Erosion and Degradation Research Group, Department of Geography, Universitat de València, Spain.

E-mail address: artemio.cerda@uv.es (A. Cerdà).
} http://dx.doi.org/10.1016/j.psep.2017.09.001

0957-5820/@ 2017 Institution of Chemical Engineers. Published by Elsevier B.V. All rights reserved. 
not restrain the enhancement of alfalfa yield. MSW compost at $40 \mathrm{tha}^{-1}$ was convinent to do not attend phytotoxic level. These results suggest that MSW compost compensates, at least partially, the negative effect of salinity on plant growth and nutrient uptake and that it is important to know soil texture to apply compost to remediate salty degraded soils. ๑) 2017 Institution of Chemical Engineers. Published by Elsevier B.V. All rights reserved.

\section{Introduction}

Good quality water resources are in high requirement around the World (Keesstra et al., 2012; Rodrigo-Comino et al., 2016; Mekonnen et al., 2017; Muluneh et al., 2017). At present, this is a critical resource for many countries and it generates social and economic disputes (Bekchanov and Lamers, 2016). Successive years of drought, induced by climate change and rapid population growth, reduced the amount of water available for agriculture in arid and semiarid regions (Mora et al., 2017; Bastida et al., 2017; Cerdà et al., 2017). This forces to use of low quality water for crop irrigation of crops (Khan et al., 2017) with negative effects on the quality of soils (Keesstra et al., 2018). The quality of irrigation water plays an important role in agricultural development and requires management to preserve agriculture soil productive (Sharma et al., 2017). Salt accumulation in Mediterranean soils is a natural process favored by the ecological conditions of the region, governed first and foremost by the water balance of the area. It does not only affect physical, chemical, and biological soil processes, but also reduces soil productivity (Ladeiro et al., 2012; Talaat et al., 2014), and soil sustainability (Garg and Singla, 2015), as well as vegetation growth. Waters of marginal quality such as drainage water, groundwater containing elevated salt concentration and treated waste water have become an important consideration in many regions of the world, even though it is being of great importance in arid, semiarid and Mediterranean areas (Gao et al., 2017; Gu et al., 2016; Kameli et al., 2017).

Tunisia is a Mediterranean country where the combination of low quality water and agricultural practices has affected the sustainability of irrigation systems what resulted an important degradation of soil resources. There is an increase in the research and the solutions to avoid the soil salinization managing the irrigation resources (Flores et al., 2017; Mora et al., 2017). Many methods are used for bioremediation of saline soil as chemical agent and leaching with water. Another important practice is the application of organic matter conditionner would be a fortunate approach that has been actualize worldwide, being effective, low cost, and simple (Tejada et al., 2006; Mbarki et al., 2010) Organic amendment application to soils in semiarid areas has become a common environmental practice for soil restoration (Amini et al., 2016; Yazdanpanah et al., 2016). Several studies have used organic amendments to recover salt-affected soils improving soil fertility, soil physical and biological properties and crop yields (Guangming et al., 2017; Meena et al., 2016; Trivedi et al., 2017). Composts have been investigated for their effectiveness in soil remediation and plant yield improvement under saline conditions. Their utilization may promote nutrient availability and plant growth (Lakhdar et al., 2008; Trivedi et al., 2017), and stimulate respiration, photosynthesis, and chlorophyll content of forage plants (Lakhdar et al., 2008). Our study will help provide guidance on selection plant variety and organic matters in ameliorating saline soil while considering their environmental concerns. However, the agricultural excessive application of composts or their low quality can had environmentally prospect because of the accumulation heavy metals ( $\mathrm{Cu}, \mathrm{Zn}, \mathrm{Pb}$ and $\mathrm{Cd})$. This face must be taken into account to safeguard application of this byproduct as a soil conditioner (Walker et al., 2004; Mbarki et al., 2016). It has been suggested that plant responses to soil amendment are soil-type specific (Mbarki et al., 2008; Papafillipaki et al., 2015). plant indicators (i.e. nutrients, bioaccumulation and transfer factor) used to highlight their impact on soil properties and to evaluate the response of plants to the different growth media (Mingorance et al., 2017).

The objective of the present work is to investigate the effect of a dried MSW compost on the growth, nutrient content and heavy metals bioaccumulation of a native forage plant Medicago sativa variety

\begin{tabular}{|c|c|c|c|}
\hline & Clay soil (SM) & Sandy soil (SN) & MSW Compos \\
\hline Clay (\%) & 34.9 & 10 & nd \\
\hline silt (\%) & 23.7 & 9 & nd \\
\hline Sand (\%) & 39.8 & 81 & nd \\
\hline $\mathrm{pH}$ & $8.27 \pm 0.01$ & $7.90 \pm 0.19$ & $8.12 \pm 0.01$ \\
\hline $\mathrm{CE}(\mu \mathrm{s} . \mathrm{cm}-1)$ & $305.33 \pm 13.37$ & $115.43 \pm 9.04$ & $8.1810^{3} \pm 0.02$ \\
\hline Total nitrogen $(\mathrm{g} / \mathrm{kg})$ & $1.06 \pm 0.05$ & $0.723 \pm 0.02$ & $13.2 \pm 1.02$ \\
\hline СОТ $(g / k g)$ & $11.09 \pm 1.03$ & $5.1 \pm 0.14$ & $143.35 \pm 3.12$ \\
\hline $\mathrm{C} / \mathrm{N}$ & nd & Nd & 10.43 \\
\hline Zinc (mg/kg) & $109.07 \pm 1.12$ & $34.45 \pm 0.38$ & $384.20 \pm 28.4$ \\
\hline Copper (mg/kg) & $50.56 \pm 0.43$ & $10.66 \pm 0.09$ & $90.54 \pm 8.08$ \\
\hline Plomb (mg/kg) & $42.58 \pm 0.96$ & $16.71 \pm 0.40$ & $112.72 \pm 2.5$ \\
\hline Cadmium (mg $/ \mathrm{kg})$ & $3.83 \pm 0.1$ & $1.90 \pm 0.01$ & $11.66 \pm 0.04$ \\
\hline
\end{tabular}

Gabes cultivated in two different soil textures to determine if combining both MSW compost and native plants M. sativa permits to improve soil quality and attempt soil restoration.

\section{Materials and methods}

A pot experiment was conducted in a semi-controlled greenhouse on clay (Cl) and sandy (Sa) soils (0-20 cm deep) collected from Morneg $\left(36^{\circ} 41^{\prime} \mathrm{N} 10^{\circ} 19^{\prime} \mathrm{E}\right)$ (field cultivated for horticultural production) and Nabeul $\left(36^{\circ} 27^{\prime} \mathrm{N} 10^{\circ} 44^{\prime} \mathrm{E}\right)$ (field cultivated for citrus orchard) respectively. The experiment was carry out under controlled conditions (temperatures (night/day) of $18 / 25^{\circ} \mathrm{C}$ and relative humidity of $70 / 80 \%$ ). Three germinated alfalfa seeds (Varity Gabes, INRAT, Tunisia) were sown in each pot with $2 \mathrm{~kg}$ of air-dried soil (thoroughly mixed and sieved at $2 \mathrm{~mm}$ ) supplemented with 0 and $40 \mathrm{tha}^{-1}$ ) of dried municipal solid waste (MSW) compost application. The MSW compost was prepared from a mixture of the separated and shredded organic fraction of household rubbish and garden waste by aerobic fermentation in a pilot composting station situated in Beja (approximately $100 \mathrm{~km}$ west of Tunis). The stepwise addition of $6 \mathrm{~g} / \mathrm{l} \mathrm{NaCl}$ to the basic nutrient solution began after a period of 2 weeks from sowing. Table 1 contains the characteristics of compost, clay and sandy soil. Thus 4 treatments for each soil were obtained: treatments irrigated with distilled water (no salty water, C: Control, Co: compost) and treatments irrigated with salty water $(\mathrm{C}+\mathrm{S}$ : non amended soil irrigated with salty water, $\mathrm{Co}+\mathrm{S}$ : amended soil irrigated with salty water). Each experimental treatment was performed using 6 replicated pots.

Compost and soil samples were dried and ground to pass $2 \mathrm{~mm}$ sieve before analysis determinations. The $\mathrm{pH}$ and Electric Conductivity (EC) were recorded on a soil (1:5) and compost (1:10) aqueous suspension using a digital $\mathrm{pH}$-meter standard LPH203T and a conductimeter standard CDRV 62, respectively. Total Nitrogen (TN) was determined by the Kjeldahl method and Total Organic Carbon (TOC) content was determined using the Anne method (Baize 2000). Sodium (Na) and Potassium (K) were assayed by flame photometry (flame photometer, Corn- 
Table 2 - Plant growth, shoot dry matter $\left(\mathrm{mg} \mathrm{plant}^{-1}\right)$ of Medicago sativa plants grown in clay (SM) or sandy(SN) soils amended or not with MSWC at 40 tons per hectares; and irrigated or not with saline water at $6 \mathrm{gl}^{-1} \mathrm{NaCl}$ after 20 days of sowing. (C): Control treatment without salt orcompost. (S): control irrigated withdistelled water added with $6 \mathrm{~g} \mathrm{l}^{-1}$ $\mathrm{NaCl}$.(CO): soil amended of $40 \mathrm{tha}^{-1}$ of compost and irrigated with tapwater. (CO+S): soil amended by $40 \mathrm{tha}^{-1}$ of compost and irrigated with tapwater added $6 \mathrm{gl}^{-1} \mathrm{NaCl}$. The first harvest (C1) was carried out on shoots, after 45 days of sowing. The others harvests were done at approximately 40 days intervals. Data are the mean of 10 replicates \pm SE. Means followed by thesame letters are not significantly different according to the Duncan's Multiple Range Test at $P \leq 0.05$.

C

\begin{tabular}{|c|c|c|c|c|c|c|c|c|}
\hline \multirow[b]{2}{*}{ Soil type } & & & & \\
\hline & SM & $\mathrm{SN}$ & SM & SN & $\mathrm{SM}$ & $\mathrm{SN}$ & SM & SN \\
\hline & \multicolumn{8}{|c|}{ Shoot Dry Weight (mg plant ${ }^{-1}$ ) } \\
\hline Cut 1 & $114.6 \mathrm{c}$ & $120.0 \mathrm{~cd}$ & $41.9 a$ & $54.1 \mathrm{ab}$ & $148.8 \mathrm{e}$ & $127.7 d$ & $42.57 a$ & $47.51 \mathrm{ab}$ \\
\hline Cut 2 & $330.1 \mathrm{e}$ & $287.6 d$ & $153.6 b$ & $118.9 a$ & $476.5 \mathrm{~g}$ & $351.7 f$ & $196.3 c$ & $177.5 b$ \\
\hline Cut 3 & $429.7 d$ & $287.3 b$ & $276.3 b$ & $90.7 \mathrm{a}$ & $475.1 d$ & $329.8 c$ & $347.4 \mathrm{c}$ & $110.9 a$ \\
\hline \multirow[t]{3}{*}{ Sum } & $844.5 \mathrm{e}$ & $662.4 d$ & $465.3 c$ & $299.8 \mathrm{a}$ & $1103.7 f$ & $822.1 \mathrm{e}$ & $485.8 \mathrm{c}$ & $395.1 b$ \\
\hline & \multicolumn{8}{|c|}{ Root Dry Weight (mg plant ${ }^{-1}$ ) } \\
\hline & $240.9 .1 \mathrm{~g}$ & $177.9 d$ & $115.7 c$ & $47.6 \mathrm{a}$ & $339.8 \mathrm{~h}$ & $223.2 f$ & $197.1 \mathrm{e}$ & $90.1 b$ \\
\hline
\end{tabular}

ing M410, UK) and heavy metal (Zinc: Zn, Cooper: $\mathrm{Cu}$, Lead: $\mathrm{Pb}$ and Cadmium: $\mathrm{Cd}$ ) concentrations were determined by atomic absorption spectrophotometry (Perkin Elmer model 3300) after nitro-fluorhydric acid digestion.

Plant growth yields were determined on harvest at the beginning of flowering (10-20\%). The plant cuts were done at 55, 95 and 140 days from sown. At the end of the experiment, roots were washed free of soil, dried, weighed and analysed. Shoot samples were collected, dried at $70^{\circ} \mathrm{C}$ for $48 \mathrm{~h}$, weighed, and ground for chemical analysis. Total Nitrogen (TN), Sodium $(\mathrm{Na})$ and Potassium $(\mathrm{K})$, Phosphorus $(\mathrm{P})$ and heavy metal: Zinc $(\mathrm{Zn})$, Copper $(\mathrm{Cu})$, Lead $(\mathrm{Pb})$ and Cadmium $(\mathrm{Cd})$ concentrations were determined.

Translocation factor: TF. Cd and Pb translocation from shoot to root was quantified by $\mathrm{TF}$ as: $\mathrm{TF}=\mathrm{Cshoot} / \mathrm{Croot}$, which Cshoot and Croot correspond to metal concentrations in the shoot $\left(\mathrm{mg} \mathrm{kg}^{-1}\right)$ and rootof the plants $\left(\mathrm{mg} \mathrm{kg}^{-1}\right)$, respectively. $\mathrm{TF}>1$ represents that translocation of metals was effective from the roots to the shoot (Li et al., 2007).

Bioaccumulation factor: BAF shoots. BAF of $\mathrm{Cd}$ and $\mathrm{Pb}$ was calculated as: BAF $=$ Cshoot/Csoil (Li et al., 2007). Cshoot and Csoil correspond to the metal concentrations in plant shoot $\left(\mathrm{mg} \mathrm{kg}^{-1}\right)$ and soil $\left(\mathrm{mg} \mathrm{kg}^{-1}\right)$, respectively.

Statistical analysis of results was carried out with SPSS software 22. Data were subjected to one-way ANOVA test and means were compared using Duncan's Multiple Range Test (DMRT) Significant differences were considered a $\mathrm{p}<0.05$. Data also were compared using multifactorial Anova (Statistica software)

\section{Results}

\subsection{Plant growth}

The results highlights that Alfalfa growth in the second and third cut is significantly higher than the first one (cut 1), generally the shoot dry weight increased by a factor of two to three times from first cut to third cut for plants grown in clay soil; however, the plant dry biomass for major treatments increased in second cut but growth remained the same in third cutting in sandy soil (Table 2). In soils irrigated with non-salt irrigation, regardless of soil types, plant growth rate at vegetative stage was significantly higher for plants grown in compost amended soil than that in control soil. This beneficial effect of compost is much more pronounced on clay soil and the effect of compost and soil types is highly significant. The shoot dry weight was significantly ( $\mathrm{p} \leq 0.05)$ affected by salt water irrigation for both soils. Salt stress is more pronounced on sandy soil than clay soil (percentage of growth compared to control treatment $55 \%$ for SM (clay soil) and $45 \%$ for SN (sandy soil)) then, salt effect is high significant depending on soil types. Under salt irrigation, compost increased the productivity of Alfalfa during second and third cut but did not improve in first cut for the clay soil. Compost improved the productivity of plants grown on sandy soil only in the second harvest without reaching the values of control soil; even the cumulative dry weight is improved in sandy soil (Table 2). Compost increased the production of dry matter roots of plants grown in the two types of soil ( $140 \%$ for SM, $125 \%$ for SN) in soil irrigated with distilled water. Dry weight production is significantly higher on clay soil than on sandy soil independent of treatments. In nonamended soil, the growth is reduced significantly by salt stress (50\% in SM clay soil, $26 \%$ SN sandy soil; compared to control soil). Salty water supplying compost, increased significantly $40 \%$ growth on clay soil and $20 \%$ on sandy soil but these cases remained below control soil (irrigated with distilled water) (Table 2). The effect of soil types compost addition and salt stress on roots biomass production is highly significant.

\subsection{Nitrogen, Potassium, Phosphorus and Sodium}

For the same treatment, control plants shoot reduced Nitrogen concentration showed no significant difference dependent to the two types of soils (Fig. 1). On the clay soil, N concentration was maintained unchanged regardless of the different treatments, tenors ranging between $\left(0.58\right.$ and $1.53 \mathrm{mmol} \mathrm{g}^{-1}$ DW); whereas on sandy soil, significantly increased when salt was incorporated respect the same treatment with no salt, reaching values of $\left(2.47\right.$ and $\left.4.04 \mathrm{mmol} \mathrm{g}^{-1} \mathrm{DW}\right)$. The Nitrogen $(\mathrm{N})$ contents of the plant tissues were significantly greater for salt treatments in sandy soil compared to those found in plant grown in the control soil. Salt effect is highly significant and depended significantly on soil types. Both salinity and compost enhanced significantly Phosphorus (P) level in plants cultivated on clay by more than $50 \%$ and their combined effect increased it by $81.4 \%$. On sandy soil, however, the only significant variation recorded was a decrease by $24.4 \%$ in $\mathrm{S}$ treatment. The $\mathrm{P}$ contents in shoots tissues are between $(0.07$ and $0.12 \mathrm{mmol} \mathrm{g}^{-1} \mathrm{DW}$ ) for plants grown in the two textures soils. Control plants cultivated on clay soil experienced lower shoot $\mathrm{P}$ concentration compared to those grown on sandy soil (Fig. 1). In control plants, Potassium (K) concentrations 

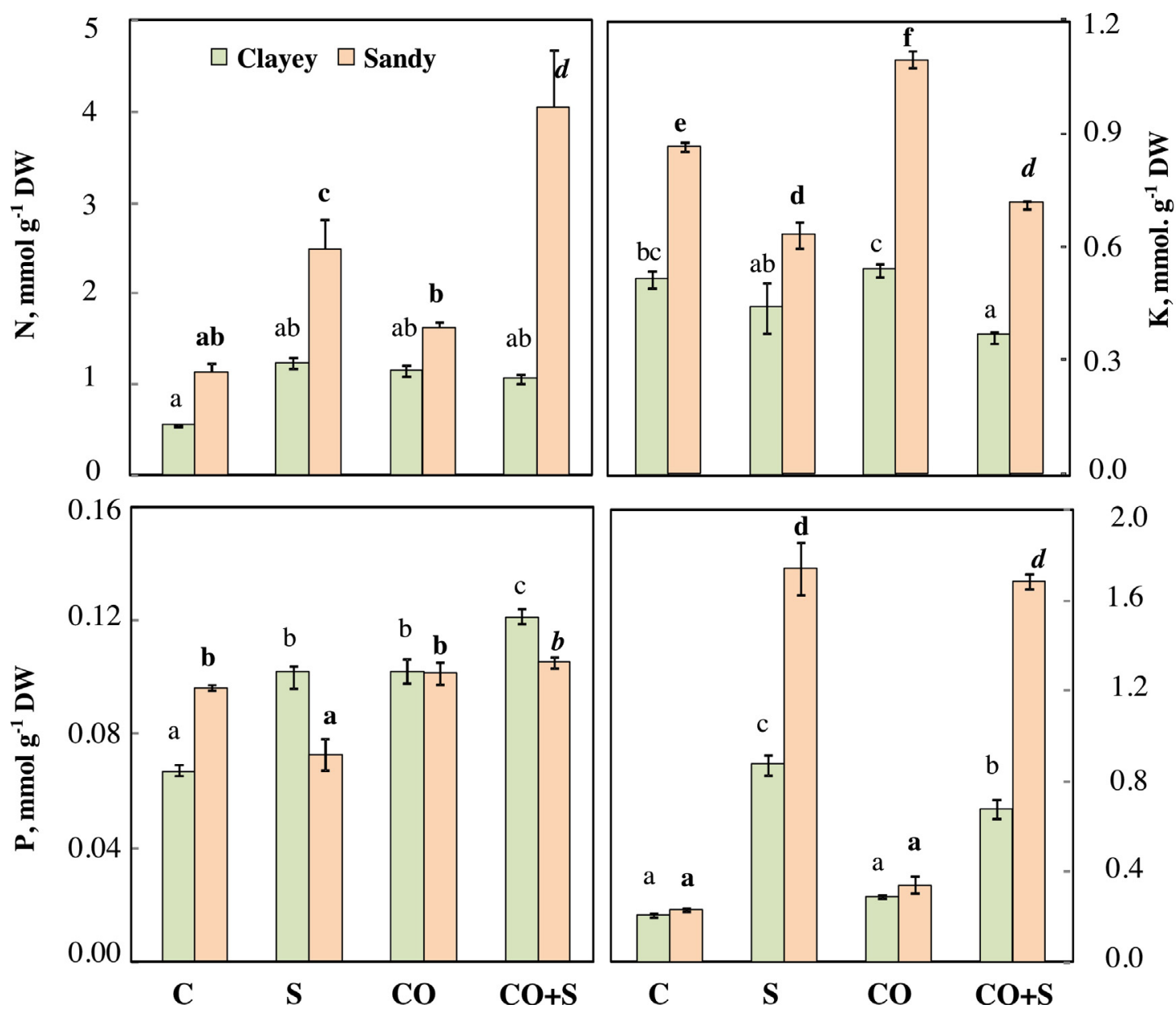

Fig. 1 - Nitrogen $(\mathrm{N})$, phosphorus $(\mathrm{P})$, potassium $(\mathrm{K})$ and sodium $(\mathrm{Na})$ concentrations in shoots of alfalfa plants grown for 6 months on clayey and sandy soils amended or not with MSW Compost and irrigated or not with saline water $\left(6 \mathrm{~g} \mathrm{NaCl} \mathrm{l}^{-1}\right)$. Bars are means of 6 pot replicates. Bars labelled with the same letter are not significantly different according to Duncan's test at $P \leq 0.05$. C: control, S: salinity, CO: compost, $\mathrm{CO}+\mathrm{S}$ : compost + salinity.

were higher on sandy than on clay soil (Fig. 1). Potassium status was ameliorated only in CO treatment on sandy soil $(+26.1 \%)$; in all other cases, it was either affected (in $\mathrm{CO}+\mathrm{S}$ treatment regardless of the soil type and in $\mathrm{S}$ treatment on sandy soil) or maintained constant (in S and CO treatments on clayey soil). The plant cultivated on sandy soil experienced higher shoot K compared to those grown on clay soil. The compost application significantly increased the plant potassium contents in sandy soil but not in clay soil. In general, salt treatments produced a decrease of $\mathrm{K}$, being clearly significant for sandy soil (Potassium in shoots is affected highly significant by, salt stress, soil types and compost application). Control and compost treatment presented less than $0.4 \mathrm{mmol} \mathrm{g}^{-1} \mathrm{DW}$ $\mathrm{Na}$ content in plant shoots. Plants irrigated with salty water accumulated much more sodium on sandy soil $\left(1.74 \mathrm{mmol} \mathrm{g}^{-1}\right.$ DW) than on clay one $\left(0.87 \mathrm{mmol} \mathrm{g}^{-1} \mathrm{DW}\right.$; Fig. 1). Compost did not reduce sodium accumulation in aerial parts on sandy soil, whereas it slightly reduced it in those grown on clay soil. The effect of irrigation with salt on Na content in shoots is highly dependent on soil types and compost treatments.

\subsection{Heavy metals}

Zinc $(\mathrm{Zn})$, Copper $(\mathrm{Cu})$, Lead $(\mathrm{Pb})$ and Cadmium $(\mathrm{Cd})$ concentrations showed the same trend for both soil types (Fig. 2A and B). They increased by salinity to $124-189 \%$, the highest rise was found in $\mathrm{Cu}$ concentration on clay soil. Salt stress affected highly significant heavy metals concentration in shoots and roots. A higher shoot accumulation of heavy metals (up to $305 \%$ of the control) was noticed in the presence of compost with no difference between salt-treated and non-treated plants. Salt and compost are the dependent variable which highly significant affected heavy metals (Zn, $\mathrm{Cu}, \mathrm{Pb}$ and $\mathrm{Cd}$ ) concentration. The order of metal uptake was: $\mathrm{Zn}>\mathrm{Cu}>\mathrm{Pb}>\mathrm{Cd}$. The salt stress increased heavy metals uptake for plant grown without amendments but in presence of compost the $\mathrm{Cu}, \mathrm{Zn}, \mathrm{Pb}$ and $\mathrm{Cd}$ content was not affected (Fig. 2A, and B). The effect size of compost on $\mathrm{Zn}, \mathrm{Cu}, \mathrm{Pb}$ and Cd concentration $\left(\eta^{2^{\prime}}=0.68,0.81,0.84\right.$ and 0.84$)$ was high compared to soil types $\left(\eta^{2^{\prime}}=0.30,0.01,0.25\right.$ and 0.17$)$ or salt concentration $\left(\eta^{2^{\prime}}=0.19,0.26,0.47\right.$ and 0.33$)$ based on Multifactor Anova.

For both texture treatments, the translocation factor (TF) for the heavy metals ( $\mathrm{Zn}, \mathrm{Cu}, \mathrm{Pb}$ and $\mathrm{Cd}$ ) was lower than 1, but for $\mathrm{Cd}$, the treatment $\mathrm{CO}+\mathrm{S}$ presented this one higher than one. This TF was higher in sandy soil compared to clay soil. Bioaccumulation factor (BAF) of $\mathrm{Zn}, \mathrm{Cu}$ and $\mathrm{Pb}$ was lower than 1 in clay soil while it was higher than 1 in sandy soil (Table 3). The salt stress increased TF and BAF for plants grown in two unamended soils types studied. The presence of compost did not increase translocation factors in clay soil whereas in sandy soil these factors showed an increase. 

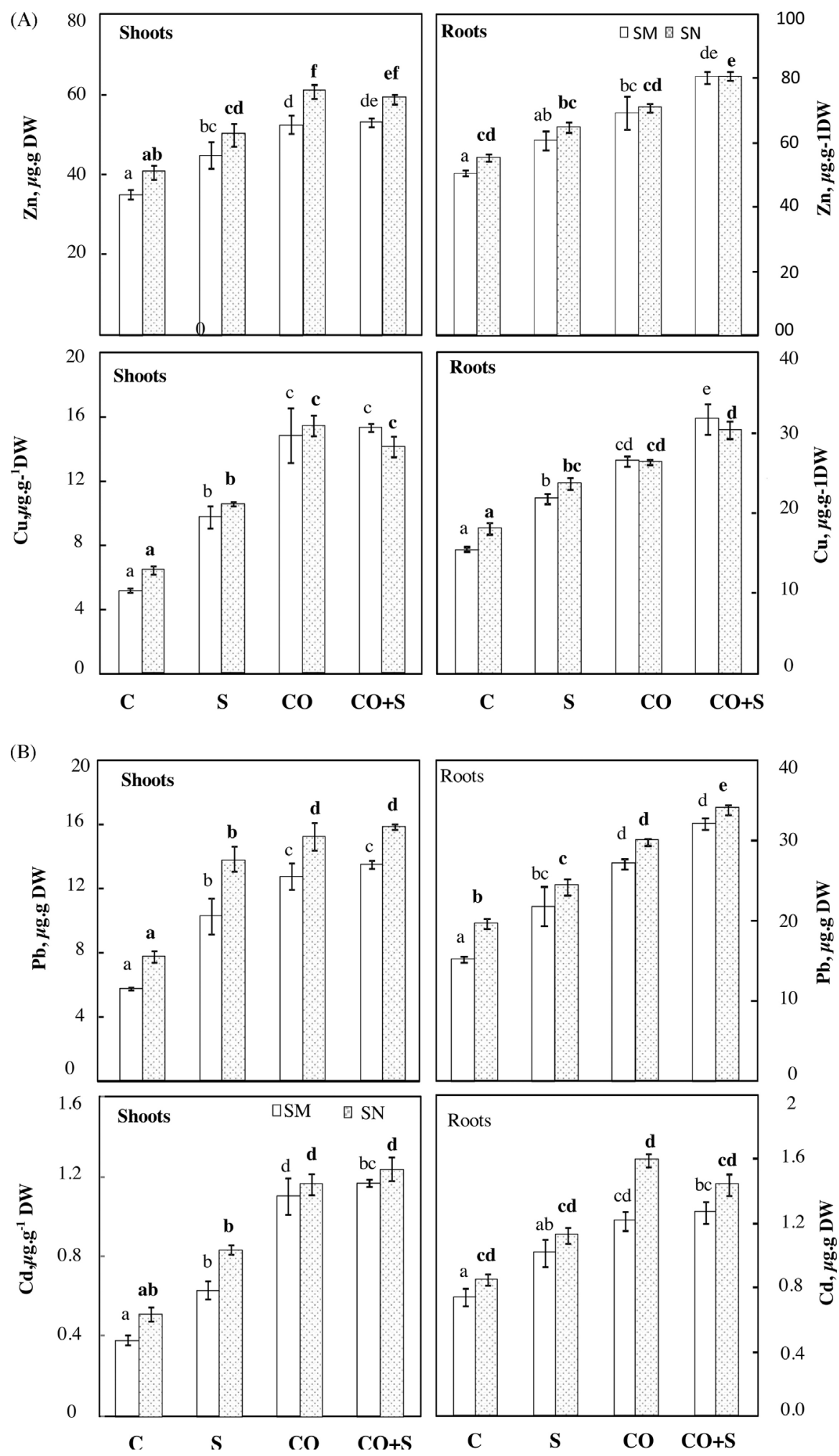

Fig. 2 - A Zinc and Copper concentrations ( $\mu \mathrm{gg}^{-1} \mathrm{DW}$ ) of alfalfa shoots and roots grown in two types of soils clay soil (SM) sandy soil (SN) amended or not with MSW Compost and irrigated or not with saline water at $6 \mathrm{~g} / \mathrm{l}$. (C): Control treatment without salt or compost. (S): control irrigated with distilled water added with $6 \mathrm{gl}^{-1} \mathrm{NaCl}$. (C0): soil amended of $40 \mathrm{tha}^{-1}$ of compost and irrigated with distilled water. $(\mathrm{CO}+\mathrm{S})$ : soil amended by $40 \mathrm{tha}^{-1}$ of compost and irrigated with tap water added $6 \mathrm{gl}^{-1} \mathrm{NaCl}$. Means of 6 replicated pots. Values followed by the same letter within a line are not significantly different at $P<0.05$. B Lead and cadmium concentrations ( $\mu \mathrm{g} \mathrm{g}^{-1} \mathrm{DW}$ ) of alfalfa shoots and roots grown in two types of soils clay soil (SM) sandy soil (SN) amended or not with MSW Compost and irrigated or not with saline water at $6 \mathrm{~g} / \mathrm{l}$. (C): Control treatment without salt or compost. (S): control irrigated with distilled water added with $6 \mathrm{gl}^{-1} \mathrm{NaCl}$. (C0): soil amended of $40 \mathrm{tha}^{-1}$ of compost and irrigated with distilled water. $(\mathrm{CO}+\mathrm{S})$ : soil amended by $40 \mathrm{tha}^{-1}$ of compost and irrigated with tap water added $6 \mathrm{~g} \mathrm{l}^{-1} \mathrm{NaCl}$. Means of 6 replicated pots. Values followed by the same letter within a line are not significantly different at $P<0$. 


\begin{tabular}{|c|c|c|c|c|c|c|c|c|c|}
\hline & & \multicolumn{2}{|c|}{ C } & \multicolumn{2}{|c|}{$\mathrm{S}$} & \multicolumn{2}{|c|}{$\mathrm{CO}$} & \multicolumn{2}{|c|}{$\mathrm{CO}+\mathrm{S}$} \\
\hline & & SM & SN & SM & SN & SM & SN & SM & SN \\
\hline \multirow[t]{2}{*}{ Zinc } & $\mathrm{TF}$ & 0.70 & 0.74 & 0.74 & 0.78 & 0.78 & 0.85 & 0.78 & 0.85 \\
\hline & BAF & 0.32 & 1.18 & 0.41 & 1.45 & 0.40 & 1.44 & 0.48 & 1.61 \\
\hline \multirow[t]{2}{*}{ Cooper } & $\mathrm{TF}$ & 0.33 & 0.36 & 0.44 & 0.45 & 0.56 & 0.59 & 0.64 & 0.76 \\
\hline & BAF & 0.10 & 0.60 & 0.19 & 1.06 & 0.24 & 1.08 & 0.32 & 1.61 \\
\hline \multirow[t]{2}{*}{ Plumb } & $\mathrm{TF}$ & 0.38 & 0.40 & 0.47 & 0.57 & 0.47 & 0.51 & 0.54 & 0.65 \\
\hline & BAF & 0.13 & 0.46 & 0.24 & 0.84 & 0.23 & 0.82 & 0.31 & 1.18 \\
\hline \multirow[t]{2}{*}{ Cadmium } & $\mathrm{TF}$ & 0.52 & 0.61 & 0.65 & 0.75 & 0.92 & 0.74 & 1.19 & 1.05 \\
\hline & BAF & 0.10 & 0.27 & 0.18 & 0.47 & 0.26 & 0.37 & 0.35 & 0.49 \\
\hline
\end{tabular}

\section{Discussion}

\subsection{Plant growth}

The effect of compost application to total plant biomass showed a significant increase. This effect depends upon the salt tolerance of the plant species besides the initial salinity and nutrient status of the soils. When the salinity stress is more severe than any nutrient deficiency, increasing the nutrient supply may not improve growth. The majority of the crop and forage species used in modern agriculture are salt sensitive and can handle only a very limited concentration of salinity (Panta et al., 2014). The alfalfa variety chosen for this study was a native species from saline habitats in tufts halophyte plants and is known for its relative tolerance to salt and heavy metals accumulation (Mingorance et al., 2017). Therefore, the compost amendment produced a plant growth promotion due to the compost mineralization that produces a nutrient release. The recovery of the vegetation biomass is a key factor of the success of the restoration of degraded land and this also affects the root system (Ni et al., 2015; Ola et al., 2015), then compost is contributing also to the land restoration. Compost mineralization would explain non differences for amended and non-amended soil plant yield. Arancon et al. (2003) also suggested that the plant growth response would be attributed to a potential hormone-like compound present in compost or to potential growth regulators adsorbed into humic acid which influence growth positively (Ouni et al., 2014). At the same time, the microbial biomass incorporated with the compost contribute biomasses incorporated with the compost contribute to reduce $\mathrm{Na}$ mobility or translocation to plant through chelation (Warman et al., 2009). MSW compost ameliorated the plant productivity due to the improved of SOC content (Mbarki et al., 2008; Webber et al., 2014). Papafilippaki et al. (2015) reported that MSW compost addition improved soil fertility by increasing the concentrations of major macronutrients having a greater impact on sandy soil because this soil contains low mineral and organic colloids (Webber et al., 2007). Similar findings were found by Srivastava et al. (2016); Luo et al. (2017) and Trivedi et al. (2017).

\subsection{Nitrogen, Potassium, Phosphorus and Sodium}

The difference of whole plant biomass systematically observed between clay and sandy soils (independently of salt application) evidences the importance of soil nature for plant growth. Recently, it has shown similar evidences although our results add information illustrating the strong interac- tion existing between compost and soil nature on plant growth (Mbarki et al., 2008; Papafilipaki et al., 2015). Simultaneously, the amended organic loads appeared to reduce mobility of accumulated Na by chelation, so that the plants are partially protected of the harmful effect of high Na concentration in the soil. The increase of dry biomass weight in compost-supplemented soil is suggested to be a result of the higher organic matter content, and high macro and micronutrient concentrations. Thus, compost amendment may attenuate the decrease of plant productivity expected because of increasing salt concentrations due to salty water irrigation. Na concentration and the mineral contents of the shoots suggested that the growth of alfalfa decrease was due to phytotoxic $\mathrm{Na}$ accumulation in the shoots, whereas $\mathrm{K}$ was always sufficient and non toxic in the plant (Kaya et al., 2001). Moreover, it has been demonstrated that the application of organic matter to saline soils can accelerate $\mathrm{Na}+$ leaching, decrease the water holding capacity and aggregate stability. By supplying nutrients, particularly N, P, the organic matter amendments can improve the mineral nutrient status and growth in saline soils (Fathi, 2010). However, this depends upon the salt tolerance of the plant species besides the initial salinity and nutrient status of the soils. When the salinity stress is more severe than any nutrient deficiency, increasing the nutrient supply may not improve growth. The alfalfa variety chosen for this study was a native species from saline habitats in tufts halophyte plant sand is known for its relative tolerance to salt which indicates that increasing supply of mineral nutrients under saline irrigation water could promote their growth. The concentration of $\mathrm{N}, \mathrm{P}$ and $\mathrm{K}$ at sufficient level contributed to growth stimulation because the $\mathrm{P}$ supplied by compost compensates the low P solubility in saline and alkaline soils (Munns, 2002). The higher tissue $\mathrm{N}$ content in shoots grown in the sandy soil and compost-amended soil treatment which are irrigated with salt water may have been caused by a concentration factor (plant with lower dry matter yields often have higher elemental analysis). Independently of treatments, the $\mathrm{N}$ concentration in $\mathrm{M}$. sativa varied from 2.5 to $3.1 \mathrm{mmol}$ per $\mathrm{g}$ of dry weight, being between 2 to $4 \%$ of DW. This result indicates that the plants were suitably fed. It is also possible that the symbiotic fixation of $\mathrm{N}$ would have contributed to the nutrition of M. sativa, in particular at advanced stages of its development. Unlike these results; salinity has been reported to decrease $P$ concentration in plant tissue. Most studies demonstrate that salinity increased tissue $\mathrm{P}$ concentrations were conducted in sands (Mbarki et al., 2017). Results reported by Loecke et al. (2004) showed no effect of treatments on shoot and root $\mathrm{P}$ when growing corn using inorganic fertilizers. Mbarki et al. (2008) also showed growth stimulation in supplemented clay versus sandy soils caused by compost addition at $40 \mathrm{Mgha}^{-1}$.

The significant decrease of plant biomass for plant growth in non amended soil under salt stress has been attributed to considerable, photosynthesis and canopy structure caused essentially by the low potential of soil solution, ion toxicities and/or nutritional imbalance (Munns, 2002). Salt water containing salts is not allowed to drain below the root zone; the salt concentration of soil water will increase as plants take up water by transpiration and as evaporation occurs. Sodiuminduced dispersal also makes it difficult for plant roots to get the water and nutrients they need to survive. There is then a need to restore, rehabilitate and reuse the saline-sodic soils as they can be a source of biomass such as we show here with the Alfalfa crops. For this, the recovery of the microbial activ- 
ity and the soil organic matter is a key factor (Guangming et al., 2017; Trivedi et al., 2017). The roles of SOC in increasing crop yields under salt stress can include: promotion of root development, which can improve efficiency of water and nutrient uptake from soil, stabilization of soil structure, which improves soil permeability such as CEC and acidity. Compost may improve aeration and water infiltration and promote root development.

Shoot to root ratio (SDM/RDM) significantly increased by the MSW compost addition at the third harvest compared to first cut in the presence or not of salt in both soil types. This occurred because the plants of final harvest had the greatest root system in relation to the plants of the first harvests, reflecting the positive effects of organic amendments. It has been point out that shoot to root ratio may be sensitive to different environmental stresses (Larco et al., 2013), as it was confirmed in our assay where the presence of salt reduced the shoot to root ratio. This shoot to root ratio increased more in sandy than in clay soils in presence of salt with supply or not with compost, suggesting that clay soil is more suitable for plant tolerance to salt stress. Salt tolerance in plants is usually associated with the ability to restrict the uptake and or transport of saline ions from roots to shoots (Hajibagheri et al., 1987). The introduction of salt-tolerant perennial species is one of the most promising alternatives to overcome salinity problems (Rengasamy et al., 2003) plus compost can make substantial contributions to recovering saline areas for agriculture (Chong, 2013; Tartoura et al. 2014).

\subsection{Heavy metals}

Heavy metals are considered one of the major toxic pollutants due to their long persistence in the environment. Soil contaminated with heavy metals can present a difficult challenge for bioremediation. Some plants are capable of accumulating elevated concentrations of several heavy metals although the factors affecting this process are generally poorly understood (Czarnecki and Düring, 2015; Trujillo-González et al., 2016, 2017). Due to the concentrations of heavy metals in MSW composts, the application of MSW composts in agricultural soils could cause accumulation of heavy metals in soils and plants contaminating the food chain, as well as ground water and threatening human health and the environment. The levels of heavy metals in the environment due to MSW compost addition in soils depend on the quality of the compost, soil type and plant species. The effect of soil type on plant response to MSW compost addition is a result of various soil properties (Mbarki et al., 2008; Papafilipaki et al., 2015).

Concentrations of $\mathrm{Zn}, \mathrm{Cu}, \mathrm{Pb}$ and $\mathrm{Cd}$ were highest in plant tissues in the presence of compost compared to that grown in control soil, but they showed no-toxicity, because the concentration of the metals were within the permissible levels: $\mathrm{Cu}$ between 20-100; $\mathrm{Zn}$ between 100-400; Pb between 30-300; and $\mathrm{Cd}$ between $5-30 \mathrm{mg} \mathrm{kg}^{-1}$. The heavy metal concentration was significantly affected by the addition of compost in the two types of soils (Mbarki et al., 2008). Risk with heavy metals load was assessed by calculating TF and BAF for different elements in shoots parts. Interestingly BAF in shoots of plant amended compost was general close to that of the control indicating a limitation of plant uptake in these elements following compost supply. The substantial increase of BAF in sandy soil observed with the MSW compost suggested that metal load toward plants should be carefully monitored, since it is of great concern for plant productivity and human health.
The salt stress increased heavy metals uptake for plant grown with no compost compared with the amended soils, reflecting the remediation effect of compost to salinity.

In general, the studied heavy metals were accumulated in roots compared to shoots which is consistent with previous finding (Lakhdar et al., 2008). Such as partitioning of metals between the plant organs is a common strategy to protect the photosynthetic tissues from heavy metals toxicity. High concentrations of heavy metals inhibit root growth by altering the ribosomal RNA precursor biosynthesis of meristematic cells (Ouzounidou et al., 1992). Zinc concentration in alfalfa shoot increased with the increase of sodicity. Other report zinc concentration in shoot tissue has been found to decrease with increasing sodicity but not necessarily with increasing salinity. Previous studies have shown salinity to increase $\mathrm{Zn}$ concentration in shoot tissue, or no effects or decreased $\mathrm{Zn}$ concentrations in leaves (Rahman et al., 1993; Al-Harbi, 1995).

The presence of salt significantly increased TF in sandy soil compared to the non-salted, being this increase greater than in clay soil. This can be explained because metal uptake by p1ants may be facilitated by soil salinity (Lumsdon et al., 1995). Metals availability was different for the two assayed soil types; this is probably due the different textures that produce a high percentage capacity plus a basic $\mathrm{pH}$ less heavy metals availability (Kaschl et al., 2002; Brookes and Mcgrath, 2006). Metal availability is likely to differ as a function of soil type. In both soils types, MSW compost at $40 \mathrm{Mgha}^{-1}$ containing heavy metals did not lead to short term accumulations in soils (Mbarki et al., 2008).

\section{Conclusion}

The combining of MSW composts and alfalfa crop may be considered a good strategy for saline soil remediation allowing alfalfa plant to mitigate the effect of salt stress and heavy metal pollution on soil environments. It is need to take into account the soil texture type to determine the type of bioremediation strategy. MSW compost increased heavy metal phytoavailability, but it was different for the sandy or clay soil; nevertheless, the levels observed in plant tissues were below phytotoxic level. The presence of salt increased significantly metal loads in shoots in sandy soil compared to control, this increase is greater to that in clay soil. Therefore, the use of alfalfa could be suitable for the decontamination of heavy metals and salt from MSW Compost especially with repeating addition.

\section{Acknowledgements}

This work had been done as part of a National Research Project. We thank the Tunisian Ministry of Higher Education and Scientific Research (LR10 CBBC02) for financially supporting this program. Authors thank to the personnel of the laboratories and general services for their collaboration. Sonia Mbarki would like to acknowledge Juan Gonzalez for their helps in English correction and for writing assistance and Marek Zivcak for statistical of multifactor analysis.

\section{Appendix A. Supplementary data}

Supplementary data associated with this article can be found, in the online version, at http://dx.doi.org/10.1016/j.psep.2017.09.001. 


\section{References}

Amini, S., Ghadiri, H., Chen, C., Marschner, P., 2016. Salt-affected soils, reclamation, carbon dynamics, and biochar: a review. J. Soils Sediments 16 (3), 939-953.

Al-Harbi, A.R., 1995. Growth and nutrient composition of tomato and cucumber seedlings as affected by sodium chloride salinity and supplemental calcium. J. Plant Nutr. 18, 1403-1416.

Arancon, N.Q., Lee, S., Edwards, C.A., Atiyeh, R., 2003. Effects of humic acids derived from cattle, food and paper-waste vermicomposts on growth of greenhouse plants: the 7th international symposium on earthworm ecology . Cardiff Wales · 2002. Pedobiologia 47 (5), 741-744.

Baize, D., 2000. Guide des analyses en pédologie. INRA ed., Paris, 257 pages.

Bastida, F., Torres, I.F., Romero-Trigueros, C., Baldrian, P., Větrovský, T., Bayona, J.M., Nicolás, E., 2017. Combined effects of reduced irrigation and water quality on the soil microbial community of a citrus orchard under semi-arid conditions. Soil Biol. Biochem. 104, 226-237.

Bekchanov, M., Lamers, J.P., 2016. Economic costs of reduced irrigation water availability in Uzbekistan (Central Asia). Reg. Environ. Change 16 (8), 2369-2387.

Brookes, B.C., Mcgrath, S.P., 2006. Effect of metal toxicity on the size of the soil microbial biomass. Eur. J. Soil Sci. 35 (2), 341-346.

Cerdà, A., Rodrigo-Comino, J., Giménez-Morera, A., Keesstra, S.D., 2017. An economic, perception and biophysical approach to the use of oat straw as mulch in Mediterranean rainfed agriculture land. Ecol. Eng. 108, 162-171.

Chong, C., 2013. Relationship of soluble salt content in MSW compost media and rooting of evergreen cuttings. Compost Sci. Utilisation 8 (1), 29-35.

Czarnecki, S., Düring, R.A., 2015. Influence of long-term mineral fertilization on metal contents and properties of soil samples taken from different locations in Hesse, Germany. SOIL 1, 23-33, http://dx.doi.org/10.5194/soil-1-23-2015.

Fathi, N.O., 2010. Impact of compost on the availability and nutrients content of Vicia faba grown on saline water irrigated soil. Minufiya J. Agric. Res. 35, 1573-1585.

Flores, A.M., Shukla, M.K., Schutte, B.J., Picchioni, G., Daniel, D., 2017. Physiologic response of six plant species grown in two contrasting soils and irrigated with brackish groundwater and RO concentrate. Arid Land Res. Manage., 1-22.

Gao, X., Bai, Y., Huo, Z., Xu, X., Huang, G., Xia, Y., Steenhuis, T.S., 2017. Deficit irrigation enhances contribution of shallow groundwater to crop water consumption in arid area. Agric. Water Manage. 185, 116-125.

Garg, N., Singla, P., 2015. Naringenin- and Funneliformis mosseae-mediated alterations in redox state synchronize antioxidant network to alleviate oxidative stress in Cicer arietinum L. genotypes under salt stress. J. Plant Growth Regul., 1-16.

Gu, M.F., Li, N., Long, X.H., Brestic, M., Shao, H.B., Li, J., Mbarki, S., 2016. Accumulation capacity of ions in cabbage (Brassica oleracea L.) supplied with sea water. Plant Soil Environ. 62 (7), 314-320, http://dx.doi.org/10.17221/771/2015-PSE.

Guangming, L., Xuechen, Z., Xiuping, W., Hongbo, S., Jingsong, Y., Xiangping, W., 2017. Soil enzymes as indicators of saline soil fertility under various soil amendments. Agric. Ecosyst. Environ. 237, 274-279.

Hajibagheri, M.A., Harvey, D.M.R., Flowers, T.J., 1987. Quantitative ion distribution within root cells of salt-sensitive and salt-tolerance maize varieties. New Phytol. 105, 367-379.

Kaschl, A., Römheld, V., Chen, Y., 2002. The influence of soluble organic matter from municipal solid waste compost on trace metal leaching in calcareous soils. Sci. Total Environ. 291, 45-57.

Kaya, C., Kirnak, H., Higgs, D., 2001. Enhancement of growth and normal growth parameters by foliar application of potassium and phosphorus in tomato cultivars grown at high ( $\mathrm{NaCl})$ salinity. J. Plant Nutr. 24, 357-367.

Keesstra, S., Nunes, J., Novara, A., Finger, D., Avelar, D., Kalantari, Z., Cerdà, A., 2018. The superior effect of nature based solutions in land management for enhancing ecosystem services. Sci. Tot. Environ. 610, 997-1009.

Keesstra, S.D., Kondrlova, E., Czajka, A., Seeger, M., 2012. Assessment of the impact of riparian and channel vegetation on water and sediment retardation using a catchment and channel scale model. Netherland J. Geosci. 91, 245-256.

Khan, M.G., Alemu, H., Abebe, C., Kebenu, F., 2017. Prospects of biomass production of three pasture grasses using saline irrigation in semiarid conditions of Afar, north-east Ethiopia. Lifesci. Leafl. 83, 30-38.

Ladeiro, B., Santos, C., Oliveira, H., Deckert, J., White, J.C., 2012. Saline agriculture in the 21st century: using salt contaminated resources to cope food requirements. J. Bot. 2012, http://dx.doi.org/10.1155/2012/310705.

Lakhdar, A., Hafsi, C., Rabhi, M., Debez, A., Montemurro, F., Abdelly, C., Ouerghi, Z., 2008. Application of municipal solid waste compost reduces the negative effects of saline water in Hordeum maritimum L. Bioresour. Technol. 99 (15), 7160-7167.

Larco, H., Strik, B.C., Bryla, D.R., Sullivan, D.M., 2013. Mulch and fertilizer management practices for organic production of highbush blueberry: I: plant growth and allocation of biomass during establishment. Hortic. Sci 48, 1250-1261.

Li, M.S., Luo, Y.P., Su, Z.Y., 2007. Heavy metal concentrations in soils and plant accumulation in a restored manganese mine land in Guangxi, South China. Environ. Pollut. 147, 168-175.

Loecke, T.D., Liebman, M., Cambardella, C.A., Richard, T.L., 2004. Corn response to composting and time of application of solid swine manure. Agron. J. 96, 214-223.

Lumsdon, D.G., Evans, L.J., Bolton, K.A., 1995. The influence of pH and chloride on the retention ofcadmium, lead, mercury, and zinc by soils. J. Soil Contam. 4, 137-150.

Luo, X., Liu, G., Xia, Y., Chen, L., Jiang, Z., Zheng, H., Wang, Z., 2017. Use of biochar-compost to improve properties and productivity of the degraded coastal soil in the Yellow River Delta, China. J. Soils Sediments, 1-10.

Mbarki, S., Labidi, N., Mahmoudi, H., Jedidi, N., Abdelly, C., 2008. Contrasting effects of municipal compost on alfalfa growth in clay and in sandy soils $\mathrm{N}, \mathrm{P}, \mathrm{K}$, content and heavy metal toxicity. Bioresour. Technol. 99, 6745-6750.

Mbarki, S., Labidi, N., Talbi, O., Jdidi, N., Abdelly, C., Pascual, J.A., 2010. Ameliorative effect of municipal solid waste compost on the biological quality of mediterranean salt lake soil. Compost Sci. Utilization 18 (4), 242-248.

Mbarki, S., Cerdà, A., Brestic, M., Mahendra, R., Abdelly, C., Pascual, J.A., 2017. Vineyard compost supplemented with Trichoderma harzianum T78 improve saline soil quality. Land Degrad. Dev. 28 (3), 1028.

Meena, M.D., Joshi, P.K., Jat, H.S., Chinchmalatpure, A.R., Narjary, B., Sheoran, P., Sharma, D.K., 2016. Changes in biological and chemical properties of saline soil amended with municipal solid waste compost and chemical fertilizers in a mustard-pearl millet cropping system. Catena 140, 1-8.

Mekonnen, M., Keesstra, Baartman, S.D., Stroosnijder, J.E.L., Maroulis, J., 2017. Reducing sediment connectivity through man-made and natural sediment sinks in the Minizr Catchment, Northwest Ethiopia. Land Degrad. Develop. 28 (2), 708-717.

Mingorance, M.D., Franco, I., Rossini-Oliva, S., 2017. Application of different soil conditioners to restorate mine tailings with native (Cistus ladanifer L.) and non-native species (Medicago sativa L.). J. Geochem. Explor. 174, 35-45.

Mora, J.L., Herrero, J., Weindorf, D.C., 2017. Multivariate analysis of soil salination-desalination in a semi-arid irrigated district of Spain. Geoderma 291, 1-10.

Muluneh, A., Stroosnijder, L., Keesstra, S., Biazin, B., 2017. Adapting to climate change for food security in the Rift Valley dry lands of Ethiopia: supplemental irrigation, plant density and sowing date. J. Agric. Sci. 155 (5), 703-724 
Munns, R., 2002. Comparative physiology of salt and water stresses. Plant Cell Environ. 25, 239-250.

Ni, J., Luo, D.H., Xia, J., Zhang, Z.H., Hu, G., 2015. Vegetation in karst terrain of south western China allocates more biomass to roots. Solid Earth 6, 799-810, http://dx.doi.org/10.5194/se-6-799-2015.

Ouni, Y., Ghnaya, T., Montemurro, F., Abdelly, C., Lakhdar, A., 2014. The role of humic substances in mitigating the harmful effects of soil salinity and improve plant productivity. Int. J. Plant Prod. 8 (3), 353-374.

Ola, A., Dodd, I.C., Quinton, J.N., 2015. Can we manipulate root system architecture to control soil erosion? SOIL 1, 603-612, http://dx.doi.org/10.5194/soil-1-603-2015.

Ouzounidou, G., Elefteriou, E.P., Karataglis, S., 1992. Ecophysiological and ultrastructural effects of copper in Thlapsio chroleucum (Cruciferae). Can. J. Bot. 70, 947-957.

Panta, S., Flowers, T., Lane, P., Doyle, R., Haros, G., Shabala, S., 2014. Halophyte agriculture: success stories. Environ. Exp. Bot. 107, 71-83, http://dx.doi.org/10.1016/j.envexpbot.2014.05.006.

Papafilippaki, A., Paranychianakis, N., Nikolaidis, N.P., 2015. Effects of soil type and municipal solid waste compost as soil amendment on Cichorium spinosum (spiny chicory) growth. Sci. Hortic. 195, 195-205.

Rahman, S., Vance, G.F., Munn, L.C., 1993. Salinity induced effects on the nutrient status of soil, corn leaves and kernels. Commun. Soil Sci. Plant Anal. 24, 2251-2269.

Rengasamy, P., Chittleborough, D., Helyar, K., 2003. Root-zone constraints and plant-based solutions for dry land salinity. Plant Soil 257, 249-260.

Rodrigo-Comino, J.R., Quiquerez, A., Follain, S., Raclot, D., Le Bissonnais, Y., Casalí, J., Pereira, P., 2016. Soil erosion in sloping vineyards assessed by using botanical indicators and sediment collectors in the Ruwer-Mosel valley. Agric., Ecosyst. Environ. 233, 158-170.

Sharma, N.K., Singh, R.J., Mandal, D., Kumar, A., Alam, N.M., Keesstra, S., 2017. Increasing farmer's income and reducing soil erosion using intercropping in rainfed maize-wheat rotation of Himalaya, India. Agric., Ecosyst. Environ. 247, 43-53.

Srivastava, P.K., Gupta, M., Shikha, Singh, N., Tewari, S.K., 2016. Amelioration of sodic soil for wheat cultivation using bioaugmented organic soil amendment. Land Degrad. Dev., 2292, http://dx.doi.org/10.1002/ldr.2292.
Talaat, N.B., Ghoniem, A.E., Abdelhamid, M.T., Shawky, B.T., 2014. Effective microorganisms improve growth performance, alter nutrients acquisition and induce compatible solutes accumulation in common bean (Phaseolus vulgaris L.) plants subjected to salinity stress. Plant Growth Regul. 75, 281-295.

Trivedi, P., Singh, K., Pankaj, U., Verma, S.K., Verma, R.K., Patra, D.D., 2017. Effect of organic amendments and microbial application on sodic soil properties and growth of an aromatic crop. Ecol. Eng. 102, 127-136.

Tartoura, K.A.H., Youssef, S.A., Tartoura, E.S.A.A., 2014. Compost alleviates the negative effects of salinity via uo-regulation of antioxidants in Solanum lycopersicum L. plants. Plant Growth Regul. 74 (3), 299-310, http://dx.doi.org/10.1007/s10725-014-9923-y.

Trujillo-González, J.M., Mahecha-Pulido, J.D., Torres-Mora, M.A., Brevik, E.C., Keesstra, S.D., Jiménez-Ballesta, R., 2017. Impact of potentially contaminated river water on agricultural irrigated soils in an equatorial climate. Agriculture 7 (7), 52.

Trujillo-González, J.M., Torres-Mora, M.A., Keesstra, S., Brevik, E.C., Jiménez-Ballesta, R., 2016. Heavy metal accumulation related to population density in road dust samples taken from urban sites under different land uses. Sci. Tot. Environ. 553, 636-642, http://dx.doi.org/10.1016/j.scitotenv.2016.02.101.

Walker, D.J., Clemente, R., Bernal, M.P., 2004. Contrasting effects of manure and compost on soil $\mathrm{pH}$, heavy metal availability and growth of Chenopodium album L. in a soil contaminated by pyritic mine waste. Chemosphere 57, 215-224.

Warman, P.R., Burnham, J.C., Eaton, L.J., 2009. Effects of repeated applications of municipal solid waste compost and fertilizers to three low bush blueberry fields. Sci. Hortic. 122 (3), 393-398.

Webber, J., Kocowicz, A., Bekier, J., Jamroz, E., Tyszka, R., Debicka, M., Kordas, L., 2014. The effect of a sandy soil amendment with municipal solid waste (MSW) compost on nitrogen uptake efficiency by plants. Eur. J. Agron. 54, 54-60.

Yazdanpanah, N., Mahmoodabadi, M., Cerdà, A., 2016. The impact of organic amendments on soil hydrology, structure and microbial respiration in semiarid lands. Geoderma 266, 58-65, http://dx.doi.org/10.1016/j.geoderma.2015.11.032. 